\title{
PEMBELAJARAN BERBICARA UNTUK MEMBANGUN KOMUNIKASI BELAJAR EFEKTIF
}

\author{
Dahliah Patiung \\ Fakultas Tarbiyah dan Keguruan UIN Alauddin Makassar \\ Kampus II: Jalan H.M. Yasin Limpo Nomor 36 Samata-Gowa \\ Email: dahliahpatiung@yahoo.co.id
}

\begin{abstract}
Abstrak:
Berbicara dalam situasi formal bukanlah hal yang mudah. Bahkan orang pintar dan berpendidikan tingggi belum tentu mahir dan terampil berbicara. Banyak di antara kita, khususnya pelajar yang masih takut untuk menjadi pembicara di depan banyak orang, sekalipun berbicara di depan teman-temannya. Dalam aktivitas interaksi, dibutuhkan strategi agar pesan yang disampaikan kepada lawan bicara dapat diterima dan dipahami dengan baik. Kegiatan berkomunikasi dapat dibagi menjadi dua ranah, yakni: ranah formal dan ranah nonformal. Komunikasi dalam ranah formal artinya menyampaikan informasi kepada lawan bicara dalam forum resmi dengan tema tertentu dan dengan adab serta kostum resmi. Kegiatan ini biasanya diwujudkan dalam bentuk berbicara di depan banyak orang atau forum. Adapun berkomunikasi dalam ranah nonformal artinya menyampaikan informasi kepada lawan bicara dalam situasi tidak resmi. Istilah ilmiah dari kegiatan tersebut dikatakan sebagai public speaking atau berbicara di depan banyak orang.
\end{abstract}

\begin{abstract}
:
Speaking in formal situations is not easy. Even the intelligent and educated persons are not necessarily adept and skillful in speaking. Many of us, especially students who are still afraid to speak in front of many people, even speaking in front of their friends. In interacting activity, of course, it takes strategy so that the message conveyed to listeners can be received and understood. Communication activities can be divided into two domains, namely formal and non-formal. Communication in the formal domain means to communicate information to the other person in an official forum with a specific theme and with manners as well as the official costume. This activity is usually manifested in the form of speaking in front of people or forums. Communicated in the non-formal domain means to convey information to listeners in informal situations. The scientific term of activities may be regarded as public speaking or speaking in front of people.
\end{abstract}

Kata Kunci:

Pembelajaran berbicara, komunikasi belajar efektif

TIDAK dapat dipungkiri bahwa peran manusia sebagai makhluk sosial pastilah akan bertemu dan berinteraksi satu sama lain. Dalam aktivitas berinteraksi, tentunya dibutuhkan strategi agar pesan yang disampaikan kepada lawan bicara dapat diterima dan dipahami dengan baik. Kegiatan berkomunikasi dapat dibagi menjadi dua ranah, yakni ranah formal dan ranah nonformal. Komunikasi dalam ranah formal artinya menyampaikan informasi kepada lawan bicara dalam forum resmi dengan tema tertentu dan dengan adab serta kostum resmi. Kegiatan ini biasanya diwujudkan dalam bentuk berbicara di depan banyak orang atau suatu forum. 
Adapun berkomunikasi dalam ranah nonformal berarti penyampaian informasi kepada lawan bicara dalam situasi tidak resmi. Istilah ilmiah dari kegiatan tersebut dikatakan sebagai public speaking atau berbicara di depan banyak orang. Akan tetapi, pada pembahasan kali ini akan lebih difokuskan pada berbicara formal sebagai aktivitas penalaran. Berdasarkan paparan tersebut akan diuraikan persiapan berbicara efektif dalam situasi formal. Tujuan penulisan adalah untuk mengetahui berbicara yang efektif dalam situasi formal.

Berbicara sebagai keterampilan menyampaikan pesan melalui bahasa lisan. Melalui pesan tersebut diterima pendengar apabila disampaikan dengan nada runtut dan jelas. Seseorang pembicara publik harus bisa melakukan berbagai tugas menyampaikan informasi, menghibur, dan meyankinkan pendengarnya. Tanpa ilmu pengetahuan informasi yang disampiakan bisa salah.

Persiapan pertama untuk berbicara di depan umum adalah terfokus pada pemilihan topik yang tepat dan menarik, topik pembicaraan merupakan salah satu penunjang keefektifan berbicara. Topik pembicaraan yang bersifat ilmiah dapat diambil dari pengalaman, pengamatan, penalaran dan informasi lain yang dianggap akurat.

Tujuan berbicara bisa berlangsung efektif apabila pembicara dapat menentukan topik yang sesuai dengan lawan bicaranya. Rumusan tujuan pembicaraan secara umum ditetapkan sebelum pembicaraan dimulai. Artinya, isi pembicaraan itu akan lebih bermakna dan berlangsung secara optimal apabila dilakukan dengan rangkaian perencanaan tertentu.

\section{KAJIAN TEORI}

\section{Berbicara Dalam Situasi Formal}

Berbicara dalam situasi formal bukanlah hal yang mudah. Tidak semua orang pintar dan berpendidikan tinggi mahir dan terampil berbicara. Buktinya, banyak sekali di antara kita khususnya pelajar yang masih takut untuk berbicara di depan umum atau berbicara di depan banyak orang, bahkan di depan teman-temannya. Terkadang ada orang mampu berbicara sangat lancer di luar situasi formal. Namun, setelah diperhadapkan pada situasi formal, mereka tidak mampu menyampaikan gagasannya dengan baik karena faktor-faktor psikologis. Seringkali pembicara mengalami keadaan itu karena tidak memiliki kompetensi public speaking atau keterampilan berbicara di depan umum dalam situasi formal yang memadai. Kalaupun dapat, hanya mampu berbicara tanpa didasari oleh ilmu dan strategi yang memadai. Untuk hal-hal yang bersifat formal dan nonformal, dalam hal penampilan, mereka masih belum mampu membedakan antara dua sifat itu, baik cara menyampaikan maupun menyajikan bahan.

Menurut Tarigan dkk., berbicara adalah keterampilan untuk menyampaikan pesan melalui bahasa secara lisan. Ditambahkannya, pesan akan efektif diterima oleh pendengar apabila disampaikan dengan sajian nada yang runtut dan jelas. ${ }^{1}$

Sirait dalam Herdiansah menyebut, seorang public speaker papan atas, mendefinisikan public speaking sebagai seni yang menggabungkan semua ilmu dan kemampu- 
an yang kita miliki. Lebih lanjut ia mengatakan bahwa memberanikan berbicara di depan umum artinya siap menyampaiakan pesan kepada orang-orang yang latar belakangnya berbeda. Seorang pembicara publik harus bisa melakukan berbagai tugas sekaligus. Ia harus bisa menyampaikan informasi, menghibur, dan meyakinkan pendengarnya. Tanpa ilmu pengetahuan, informasi yang disampaikan bisa salah. Tanpa kemampuan mengingat cerita lucu dalam urutan yang betul, maka pembicara tidak akan bisa menghibur pendengar. Selanjutnya, tanpa kepercayaan diri, seorang pembicara tidak akan bisa meyakinkan orang lain untuk percaya. Intinya, public speaking yang baik dekat dengan kesuksesan. ${ }^{2}$

\section{Persiapan Berbicara dalam Situasi Formal}

Pembicara yang baik perlu mempersiapkan diri semaksimal mungkin sebelum menyampaikan materinya. Agar pembicara dapat tampil secara maksimal, maka perlu mempersiapkan beberapa hal sebagai berikut:

\section{Memilih Topik Pembicaraan}

Topik pembicaraan adalah pokok atau subjek pembicaraan. Persiapan pertama untuk berbicara di depan umum adalah terfokus kepada pemilihan topik yang tepat dan menarik. Topik pembicaraan merupakan salah satu penunjang keefektifan berbicara. Topik pembicaraan yang bersifat ilmiah dapat diambil dari pengalaman, pengamatan, penalaran, dan informasi lain yang dianggap akurat.

Menurut Gamble dan Gamble, pemilihan topik yang tepat adalah didasarkan kepada: (1) Analisis diri anda untuk mengidentifikasi bahwa topik itu menarik minat dan perhatian anda, dan secara khusus berada dalam penguasaan pengetahuan anda; (2) Analisis pendengar untuk mengidentifikasi hal-hal mengenai keinginan, kebutuhan dan pengetahuan mereka yang berdampak pada pemilian topik; (3) Identifikasi kejadian terhadap pembicaraan, termasuk setiap permintaan khusus dari penyelenggara atau adanya peristiwa alam yang menyebabkan timbulnya pembicaraan; (4) Pilih area subjek pembicaraan umum dan kemudian dipersempit pada subjek yang khusus sampai akhirnya pada subjek yang tersempit.

\section{Menentukan Tujuan, Bahan, dan Kerangka Pembicaraan}

Menentukan tujuan, bahan dan kerangka wacana pada hakikatnnya dapat mengarahkan efektifnya pembicaraan. Pembicaraan terarah dengan baik sesuai dengan apa yang diharapkan oleh pembicara. Oleh karena itu, sangat perlu diperhatikan sebelum melaksanakan aktivitas berbicara.

Pertama, menentukan tujuan. Pembicara harus dapat merumuskan secara jelas tujuan umum, tujuan khusus dan ide sentral materi yang akan dibawakan. Tujuan umum dapat berupa penyampaian informasi, membujuk, menyakinkan atau memberi instruksi kepada pendengar. Tujuan khusus suatu pembicaraan bergantung pada rumusan tujuan umum. Ide sentral adalah inti dari pembicaraan yang biasanya dikemas dalam satu kalimat yang mudah diserap dan diingat pendengar.

Perumusan tujuan berbicara akan memberikan gambaran atau perencanaan 
yang menyeluruh dan akan mengarahkan pembicara untuk menentukan atau memilih tema yang sesuai dengan lawan bicara. Rumusan tujuan pembicaraan biasanya ditetapkan jauh sebelum pembicaraan berlangsung agar isi pembicaraan dapat menjadi lebih bermakna dan kegiatannya mencapai tujuan secara optimal.

Kedua, mengumpulkan bahan atau materi pembicaraan. Mengumpulkan bahan atau meteri pembicaraan dilakukan apabila penentuan tujuan pembicaraan telah dinyatakan secara jelas. Bahan pembicaraan yang dikumpulkan harus relevan dengan tujuan pembicaraan. Isi pembicaraan dapat memenuhi standar mutu, setidaknya apabila bahan untuk pembicaraan itu dianggap telah cukup dan dikuasai oleh pembicara. Mengumpulkan bahan atau informasi antara lain dengan membaca buku dan penerbitan berkala seperti majalah, buletin, jurnal, mencari bahan dari internet, dll.

Menurut Mukti dan Maidar dalam Asdam bahwa bahan pembicaraan dapat diperoleh melalui dua unsur utama, yaitu: (1) Inferensi yang dimaksud di sini adalah kesimpulan atau nilai-nilai yang diperoleh dari berbagai pengalaman. Bahkan infensi dapat merubah menjadi suatu pengalaman yang sangat berharga dia menarik dalam kehidupan manusia; (2) Pengalaman adalah semua pengetahuan yang diperoleh melalui persepsi dan interprestasi dari seseorang karena hasil elaborasi pancaindra manusia selaku pembicara; (3) Bahan pembicaraan dapat diperoleh dari pengamatan langsung dan pengamatan tidak langsung. Pengamatan tidak langsung dapat bersumber dari bahan pustaka atau buku-buku rujukan yang dianggap sesuai dengan topik pembicaraan. Namun, yang terpenting adalah bagaimana menanggapi dan memberi interprestasi terhadap isi bacaan yang dianggap sesuai dengan materi atau bahan pembicaraan yang dibutuhkan. ${ }^{3}$

\section{Menyusun Kerangka Pembicaraan}

Kerangka pembicaraan adalah suatu pola atau acuan yang dipedomani oleh pembicara dalam menyusun dan mengembangkan suatu gagasan pokok. Kerangka pembicaraan memang sangat dibutuhkan apalagi pebicaraan yang sifatnya resmi atau formal. Pembicaraan yang sifatnya formal, seperti menjadi moderator dalam suatu acara seminar atau diskusi ilmiah, maka kerangka sangat penting artinya. Pembicaraan yang tidak mempunyai kerangka sebelum berbicara, maka isi pembicaraannya dapat saja mengambang di luar dari tujuan atau topik pembicaraan. Oleh karena itu, sebelum anda berbicara secara formal sebaiknya mempersiapkan diri termasuk penyusun kerangka wacana.

\section{Rambu-rambu Berbicara Formal}

Berbicara formal adalah berbicara yang biasa dilakukan di depan forum, yang mana terikat dengan aturan-aturan atau rambu-rambu tata krama dan kebahasaaan. Adapun rambu-rambu yang harus diprerhatikan dalam berbicara formal, yaitu antara lain sebagai berikut:

1. Mendengarkan dengan baik lawan bicara. Sikap ini sangat penting dalam berbicara karena apabila pembicara tidak memperhatikan lawan bicara boleh jadi dia akan kehilangan focus pembicaraan. 
2. Menggunakan kosa kata dan artikulasi yang jelas, nada yang pas dan intonasi yang yang baik.

3. Menggunakan kata-kata seperti "kami atau kita", karena kata-kata ini terdengar lebih sopan.

4. Tidak memotong alur pembicaraan orang lain. Beri waktu kepada orang lain untuk mengakhiri pembicaraannya, dan setelah itu barulah kita mulai berbicara karena kita pasti memilki waktu dan kesempatan untuk berbicara.

5. Menggunakan kata-kata yang baku dan mudah dimengerti orang lain.

6. Berbicara harus menatap lawan bicara anda. Ketika berbicara kita harus konsentrasi dengan baik kepada lawan bicara, jangan melihat ke arah lain sehingga membuat lawan bicara tersinggung. Menatap lawan bicara ketika sedang berbicara termasuk etika berbicara yang baik.

7. Suara harus terdengar jelas. Ketika berbicara, suara harus ditata agar pendengar atau lawan bicara dapat menangkap dengan jelas apa yang sedang dibicarakan. Tidak boleh terlalu terburu-buru dan tidak terlalu pelan. Di samping tidak efektif, pembicaraan yang kurang terdengar jelas dan terburu-buru kadang-kadang menimbulkan kejengkelan bagi pendengar atau lawan bicara.

8. Menggunakan tata bahasa yang baik dan benar. Ketika berbicara, seseorang harus mengetahui subyek, predikat dan objek serta keterangan dalam kalimatnya. Termasuk bagaimana menempatkan kalimat pada tempat yang benar agar tidak bingung dengan kalimat yang diucapkan sendiri.

9. Jangan menggunakan nada suara yang terlalu tinggi. Pada saat berbicara gunakan nada suara yang datar saja, sehingga setiap orang dapat menangkap isi pembicaraan dengan baik. Jika berbicara dengan nada terlalu tinggi dikhawatirkan tidak semua pendengar dapat mendengar dengan baik. Apalagi jika berbicara di depan forum resmi.

10. Pilih tema pembicaraan yang mudah dimengerti. Karena tujuan utama dalam berbicara adalah untuk membuat pendengar atau lawan bicara dapat mengerti apa yang sedang kita bicarakan, sebaiknya menggunakan bahasa yang sederhana dan mudah dimengerti oleh orang lain. Seringkali terdengar orang yang berbicara dengan bahasa yang tinggi namun pendengar tidak mengerti apa yang sedang dibicarakan.

11. Menggunakan bahasa yang santun dan sopan.

12. Jangan menggunakan bahasa atau kata-kata yang bertele-tele karena dapat membuat pendengar menjadi bosan. ${ }^{4}$

Jenis Berbicara dalam Situasi Formal

Pidato

Pidato adalah penyampaian idea tau gagasan secara lisan dengan memperhatikan kaidah seni berbicara. Kegiatan berpidato sering dijumpai di acara peringatan hari besar, kegiatan pelatihan, seminar ilmiah, pemimpin, dan kegiatan resmi lainnya. 
Pemimpin hars tampil di hadapan peserta dalam membuka acara atau member sambutan dalam bentuk pidato.

Harga diri dan kewibawaan seorang orator yang baik akan terpancar setiap warga dihadapi ketika sedang berpidato. Melalui berpidato yang baik dapat menjadi salah satu modal utama untuk tampil dalam satu kancah politik, akhirnya meraih satu kesuksesan dan kekuasaan.

\section{Tata Krama Berpidato}

Tata karma yang dimaksud yaitu sebagai berikut: (1) Berpidato di hadapan umum hendaknya memperhatikan cara berpakaian yang rapi dan bersih, menggunakan kata-kata yang sopan, rendah hati, diselingi humor yang ada hubungannya dengan isi pidato, berdiri atau duduk di hadapan orang banyak yang dapat dilihat oleh semua orang yang hadir; (2) Berpidato di hadapan orang yang tidak perpendidikan hendaknya menggunakan kata-kata sederhana, mudah dipahami, dan sesuai dengan pengalaman dan kenyataan yang dialami; (3) Berpidato di hadapan orang berbeda hendaknya mepersiapkan diri dengan sempurna, baik penampilan, penguasaan materi, dan tanpa rasa rendah diri; (4) Orang yang berpidato agar tidak lupa mengikuti langkah-langkah berpidato, seperti memberi penghormatan, pengucapan salam, mengucapkan puji syukur, menyampaikna pendahuluan pidato, isi pidato yang berisi ajakan, kesimpulan isi pidato, dan mengucapkan salam penutup.

2. Penunjang Keefektifan Berpidato

Hal yang menunjang dalam berpidato dapat disebut antara lain: (1) Orang yang berpidato dituntut bermoral dan tidak dalam keadaan marah atau emosi; (2) Orang yang berpidato diharapkan sehat jasmani dan rohani sehingga penampilannya secara prima, bersemangat, percaya diri, dan penuh rasa simpatik kepada pendengar; (3) Memanfaatkan dengan baik sarana dan prasana yang diperlukan dalam berpidato, seperti penggunaan pengeras suara dengan baik, mimbar, dan catatan kalau ada; (3) Memperhatikan volume suarah apabila di hadapan massa yang berjumlah banyak, memperhatikan adat-istiadat, keadaan sosial, agama, dan waktu yang ditentuan.

3. Persiapan dalam Berpidato

Seseorang yang akan berpidato perlu diawali dengan berbagai persiapan, baik yang berhubungan dengan aspek kebahasaan maupun non-kebahasaan. Aspek kebahasaan yang dimaksud adalah meguasai dan menerapkan kaidah penggunaan pelafalan bahasa Indonesia yang baku, menggunakan kalimat efektif, menggunakan berbagai gaya bahasa. Sedangakan non-kebahasaan meliputi keberanian, ketenagaan, kesanggupan berinteraksi dan bereaksi secara cepat, kesanggupan menyampaikan ide secara teratur dan sistematis, dan kesanggupan memperhatikan penampilan, gaya berbicara gerak-gerik, dan berbagai mimik yang sesuai dengan isi pembicaraan.

4. Metode Berpidato

Menyusun suatu naskah pidato biasanya mengacu pada suatu metode tertentu. Metode dalam suatu penyusunan pidato dikenal dengan beberapa jenis, yaitu: (1) serta merta (impromptu); (2) metode menghafal, (3) metode naskah, dan (4) metode tanpa persiapan naskah, penjelasan pada setiap metode yang dikemukakan di atas, yaitu sebagai berikut: 
Metode serta-merta (impromptu). Metode seperti ini kebanyakan dijumpai di kalangan pejabat dan orang sudah berpengalaman di bidangnya. Mereka menyampaikan gagasan secara tiba-tiba tanpa diawali pemberitahuan sebelumnya. Efek negatif yang ditimbulkan yaitu tidak tahu apa yang mau dibicarakan di hadapan orang banyak, akhirnya muncul rasa kaku atau tidak percaya diri.

Metode Menghafal. Metode menghafal dalam berpidato mengandalkan hafalan akan naskah dari awal sampai akhir. Menggunakan metode ini penampilannya kurang alamiah dan seolah-olah terpengaruh dengan naskah yang telah dihafal. Meraka tampil kaku, kurang percaya diri, dan kadang pengucapannya tersendat.

Metode Naskah. Metode naskah sering dipakai dalam berpidato resmi, seperti pidato yang ditayangkan dalam siaran televisi dan radio. Orang yang mebacakan pidato seolah-olah tidak memiliki hubungan psikologis dengan audiensnya. Pembaca terkadang belum dapat menjiwai isi naskah pidato yang dibacakan sehingga ekspresi kadang tidak tampak pada saat pembacaan pidato.

Naskah pidato yang tidak dikuasai sangat mempengaruhi penampilan pembicara atau orator. Orator hanya selalu menatap naskah yang telah dipersiapkan. Oleh karena itu, orang yang menerapkan metode naskah diharapkan mengusai materi dengan banyak membaca atau berlatih agar mampu memberi tekanan dan variasi suara, dan dapat menampakkan ekspresi yang sesuai.

Metode tanpa persiapan naskah atau ekstemporan. Penggunaan metode ini diawali dengan perencanaan cermat, diawali dengan perencanaan cermat dengan membuat catatan penting sekaligus menjadi urutan dalam penyajian pidato tersebut. Penggunaan metode ekstemporan umumnya dilakukan dengan mempersiapkan catatan kecil yang mendukung judul pidato yang disampaikan. Catatan kecil itu dapat saja dibawa pada waktu menyampaikan isi pidato. Catatan kecil itu dapat dilihat apabila ragu agar tidak salah menyampaikannya atau dapat saja dibawa sekedar sebagai bahan pengingat atau pembantu jika kehilangan fokus. Seseorang yang berpidato yang selalu membawa catatan kecil dan dibacanya akan menimbulkan suatu kesan bahwa dia tidak menguasai materi yang disampaikannya. Akhirnya tingkat keyakinan dan kepercayaan audiens berkurang, terutama terkait kewibawaan orator.

5. Sistematika Berpidato

Dalam menyampaikan pidato, sebaiknya pembicara memperhatikan hal-hal berikut: (1) Mengucapkan salam pembuka dan menyapa hadirin; (2) Menyampaikan pendahuluan yang biasanya dilahirkan dalam bentuk ucapan terima kasih, atau ungkapan kegembiraan atau rasa syukur; (3) Menyampaikan isi pidato yang diucapkan dengan jelas dengan menggunakan bahasa Indonesia yang baik dan benar dan dengan gaya bahasa yang menarik; (4) Menyampaikan kesimpulan dari isi pidato agar mudah diingat oleh pendengar; (5) Menyampaikan harapan yang berisi anjuran atau ajakan kepada pendengar untuk melaksanakan isi pidato; dan (6) Menyampaikan salam penutup. 


\section{Diskusi}

1. Pengertian

Diskusi adalah suatu proses tukar pendapat yang dilakukan beberapa orang tentang suatu topik. Sebuah diskusi akan bermanfaat atau bernilai ilmiah apabila tukar pendapat itu didasari hal-hal berikut: (1) Sikap saling menghargai antar peserta diskusi dijunjung tinggi dengan anggapan bahwa semua peserta diskusi mempunyai hak dan kewajiban yang setara; (2) Pengajuan pendapat menggunakan bahasa yang sopan; (3) Pendapat diutarakan dengan tujuan saling bertukar pikiran dan bukan saling menjatuhkan; dan (4) Setiap pendapat didasarkan atas fakta, teori, atau pengetahuan yang jelas dan logis.

Kemampuan seseorang berdiskusi dapat berbeda antara satu dengan lainnya. Hal ini ditentukan oleh kualitas dan kuantitas latihan seseorang berbicara di hadapan orang lain. Orang yang sering terlibat dalam diskusi, biasanya memiliki kemampuan yang lebih baik, dengan kemampuan lebih baik untuk memahami dan mengutarakan pikirannya secara lisan. Apalagi ditunjang dengan pengetahuan dan wawasan yang luas, sehingga lebih memiliki kebebasan berargumen di hadapan orang banyak.

Dermikian pula penyampaian sanggahan hendaknya dilakukan secara santun, yaitu dengan cara: (1) Jelas dan tidak berbelit-belit; (2) Diajukan secara santun dengan menghindari pertanyaan, permintaan, atau perintah langsung; (3) Agar pertanyaan dan sanggahan tidak ditafsirkan sebagai bantahan atau debat.

Dalam memberikan tanggapan pun harus memperhatikan beberapa hal, antara lain: (1) Jawaban atau tanggapan harus berhubungan dengan pertanyaan; (2) Jawaban harus objektif dan memuaskan berbagai pihak; (3) Prasangka negatif dan emosi harus dihilangkan; (4) Bersikap jujur dan terus terang apabila tidak bisa menjawab.

2. Kronologis Tugas Moderator

Diskusi membutuhkan pemandu diskusi atau moderator. Moderator adalah orang yang bertindak sebagai penengah (hakim, wasit, dan sebagainya); atau pemimpin sidang (dalam rapat atau diskusi) yang menjadi pengarah pada acara pembicaraan atau pendiskusian masalah (kbbi.web.id). ${ }^{5}$ Kegiatan diskusi dikendalikan oleh seorang moderator mulai dari awal diskusi sampai akhir. Kronologis tugas moderator dapat dirumuskan sebagai berikut:

1) Membuka Diskusi. Untuk memulai diskusi, moderator perlu menyampaikan halhal berikut:

a) Salam pembuka

b) Permasalahan diskusi

c) Latar belakang permasalahan

d) Rumusan permasalahan

2) Memperkenalkan narasumber dan notulis. Narasumber diperkenalkan secara lengkap biodatanya sebagai tanda rasa hormat di hadapan orang banyak. Sedangkan notulis cukup diperkenalkan nama lengkap dan titelnya.

3) Mempersilahkan kepada nara sumber mempersentasikan materinya kalau kondisinya memang sudah memungkinkan karena sudah aman dan tertib. Begitu pula 
mempersilahkan peserta diskusi mengajukan pertanyaan secara sopan, adil, dan bijaksana.

4) Mengarahkan diskusi hal sangat penting agar tercipta ketertiban, lancar, dan tepat penggunaan waktu, tepat topik yang dibahas, dan berusaha agar partisipasi peserta diskusi merata.

5) Menyimpulkan. Menarik kesimpulan diskusi merupakan tugas penting dari moderator. Penyampaian kesimpulan kesimpulan bisa juga dilakukan kalau waktu sangat memungkinkan. Sebaliknya, kalau waktu sangat terbatas maka bisa juga tidak disampaikan kesimpulannya.

6) Penutup, merupakan rangkaian terakhir dalam kegiatan diskusi. Di bagian membuka diskusi diucapkan "Bismillahi Rahmani Rahim" maka di bagian penutup mengucapkan "Alhamdulillahi Rabbil Alamin".

3. Diskusi Kelompok

Diskusi kelompok pada hakikatnya suatu bentuk percakapan yang melibatkan banyak orang pada setiap anggota kelompok yang dilakukan secara terarah dan berencana untuk mencapai suatu tujuan yaitu terciptanya kesepakatan dalam penyelesaian masalah pada bidang tertentu. Diskusi kelompok merupakan upaya percakapan atau pembahasan yang dipersiapkan di antara tiga atau lebih tentang topik tertentu dengan fasilitator. Dengan demikian, dapat ditegaskan bahwa diskusi kelompok merupakan suatu aktivitas tukar pendapat, buah pikiran, dan pengalaman yang dipandu oleh satu orang untuk mengarahkan kelancaran diskusi. Diskusi kelompok mempunyai tujuan mengolah pendapat yang dapat dilakukan melalui tiga cara: mengemukakan pendapat, mengkonfrontasikan antar pendapat, dan meninjau kembali dan merevisi pendirian sendiri.

Oleh karena itu, setiap orang atau lembaga yang ingin melaksanakan diskusi harus mempertahankan syarat-syarat diskusi yang baik, yaitu: (1) Merangsang anggota kelompok agar dapat lebih peka terhadap setiap perubahan dan kejadian yang terdapat dalam lingkungan atau alam sekitarnya; (2) Merangsang anggota kelompok agar dapat memberanikan diri mengeluarkan pendapatnya dalam berdiskusi; (3) Menguji tingkat kebenaran pendapat para anggota; (4) Mendorong anggota kelompok untuk mengembangkan potensi kepemimpinan dan kepribadiannya ke arah yang lebih matang dan dewasa; (5) Merangsang seseorang untuk meningkatkan kematangan berpikir secara individual dan berangkai dengan pendapat orang lain untuk membentuk pendapat baru yang memiliki dasar argumentasi yang luas dan fleksibel. ${ }^{6}$

\section{Presentasi}

Pada umumnya, presentasi digunakan untuk menyampaikan pesan, ide, atau informasi kepada audiensi (dalam berbagai situasi). Presentasi merupakan suatu kegiatan dimana seorang pembicara secara langsung kepada pendengar sehingga mereka dapat mengerti pesan yang dapat disampaikan sesuai pemahaman yang dimiliki. Hal yang harus diperhatikn dalam presentasi yaitu: (1) Berkonsentrasi pada satu topik yang dibahas; (2) Mengumpulkan bahan atau menyatukan materi presentasi; (3) 
Hindari penyampaian rasa gugup dihadapan orang banyak; dan (4) Mengurangi rasa takut.

Adapun langkah-langkah presentasi sebagai berikut: (1) Memperkenalkan diri atau kelompok; (2) Membacakan judul yang akan dipersentasikan; (3) Membuka sambil berkonsentrasi pada pesan atau informasi yang akan disampaikan; (4) Menggunakan alat bantu secara tepat seperti laptop, dan layar (screen); (5) Mulai secara perlahan, berikan permulaan yang telah dipersiapkan dengan baik dan penuh percaya diri berdiri di hadapan orang banyak; (6) Memberikan respon menjawab pertanyaan secara logis meskipun mengalami tantangan; (7) Menutup presentasi dengan kesimpulan yang tepat.

\section{Konferensi}

Konferensi merupakan bentuk pertemuan dari kedua pihak untuk membahas atau merundingkan masalah yang dihadapi bersama. Secara longgar, konferensi juga diartikan dengan pertemuan anggota-anggota dari dua cabang perwakilan untuk menyesuaikan perbedaan dalam langkah dan kebijakan mereka. Konferensi merupakan pembicaraan, rapat, atau pemusyawarahan antara wakil-wakil berbagai negara untuk membahas kepentingan bersama.

\section{Diskusi Panel}

Diskusi panel adalah diskusi yang dilakukan oleh sekelompok orang yang disebut panelis yang membahas suatu masalah atau topik yang menjadi perhatian umum di depan khalayak atau pendengar atau penonton. Misalnya, dua atau tiga orang yang mempunyai keahlian atau dianggap ahli dalam bidang tertentu mendiskusikan suatu masalah yang dipimpin oleh seorang pemandu atau moderator di hadapan khalayak, pendengar, atau penonton.

\section{Simposium}

Simposium pada dasarnya merupakan variasi dari diskusi panel. Pada kegiatan simposium, pemirsa merupakan penanggap aktif terhadap satu pokok pembicaraan yang ditinjau dari berbagai aspek. Dalam kegiatan symposium, dihadiri beberapa ahli dalam bidang yang dibicarakan.

Perbedaan simposium dan diskusi panel terletak dari status kualitas keterlibatan pemirsa. Pada diskusi panel dibatasi keterlibatan pemirsa, sedangkan pada symposium tidak dibatasi oleh keterlibatan pemirsa. Persamaannya yaitu sama-sama mengkaji hal-hal yang dianggap penting atau ilmiah.

\section{Debat}

Debat adalah diskusi yang terdiri atas dua kelompok yang saling bertentangan pendapat yang bertujuan agar tiap kelompok menentang pendapat lawannya sehingga dapat menyetujui pendapat kelompoknya. Dalam kegiatan debat tentu berhadapan antara kelompok yang pro dengan kontra saling berseteruh pendapat. 
Tujuan debat adalah melatih para anggota kelompok untuk dapat memahami pendapat orang lain secara cepat dan tepat. Langkah-langkahnya: (1) Pendahuluan, pada bagian ini ketua sidang memberikan pengarahan tentang tata tertib yang diberlakukan, mengumumkan topik, dan memperkenalkan para peserta debat; (2) Pelaksanaan debat, ketua sidang mempersilahkan salah satu anggota kelompok mengajukan suatu argumentasinya yang berhubungan dengan masalah yang dibahas, anggota kelompok kontra mengajukan tanggapan dan rasa tidak setuju dengan gagasan tersebut; (3) Rangkuman, setelah perdebatan yang berkepanjangan maka para pendebat dalam mencapai titik temu kesepakatan yang dapat dijadikan sebagai kesimpulan; dan, (4) Pembacaan hasil kesimpulan dari ketua sidang. ${ }^{7}$

\section{Seminar}

Seminar adalah suatu pertemuan yang bersifat Ilmiah untuk membahas suatu masalah tertentu dengan prasaran serta tanggapan melalui suatu diskusi untuk mendapatkan suatu keputusan bersama mengenai topik atau masalah yang akan dibahas. Seminar mempunyai tujuan: (1) Memberi andil pada penemuan yang diperoleh di lapangan; (2) Memungkinkan terjadi pertukaran pengalaman, Informasi, dan pengetahuan yang berhubungan dan pengkajian penelitian; (3) Mengembangkan rencana dan metedologi yang siap diterapkan dalam penelitian; (4) Mempertimbangkan berbagai saran untuk diterapkan dalam penelitian.

\section{Wawancara}

Wawancara adalah proses tanya jawab lisan antara dua orang atau lebih secara langsung. Pewawancara disebut sebagai interviewer dan orang yang diwawancarai disebut sebagai interviewee dan sebagai salah satu bentuk percakapan yang dilakukan oleh dua orang atau lebih untuk memperoleh suatu data, informasi, masukan, atau tujuan tertentu. Wawancara berbeda dengan bercakap-cakap biasa dengan teman akrab di berbagai tempat. Wawancara mempunyai tujuan tertentu yanng ingin dicapai oleh pewawancara. ${ }^{8}$

Jenis wawancara secara umum ada dua: (1) Wawancara terstruktur atau disebut juga wawancara terkendali. Wawancara tipe ini didasarkan pada suatu sistem atau daftar pertanyaan yang ditetapkan sebelumnya. Wawancara terstruktur ini mengacu pada situasi ketika seorang peneliti melontarkan sederet pertanyaan kepada responden berdasarkan kategori-kategori jawaban tertentu atau terbatas. Namun, peneliti dapat juga menyediakan ruang bagi variasi jawaban, atau peneliti dapat juga menggunakan metode pertanyaan terbuka yang tidak menuntut keteraturan, hanya saja pertanyaannya telah disiapkan terlebih dahulu oleh peneliti; (2) Wawancara tak terstruktur adalah wawancara yang bebas dimana peneliti tidak menggunakan pedoman wawancara yang telah tersusun secara sistematis dan lengkap untuk pengumpulan datanya. Pedoman yang digunakan hanya berupa garis-garis besar permasalahan yang akan ditanyakan. 


\section{Keefektifan Berbicara dalam Situasi Formal}

Keefektifan berbicara mencakup beberapa aspek seperti cara penyampaian, isi pembicaraan, serta proses penyampaian informasi. Utamanya dalam situasi formal, terdapat berbagai faktor yang harus diperhatikan dalam berbicara, diantaranya sebagai berikut:

1. Ketepatan ucapan pembicara. Salah satu kaedah bahasa yang harus diperhatikan pembicara adalah kaedah fonologis atau pelafalan bunyi-bunyi bahasa.

2. Penggunaan tekanan, nada, sandi, dan durasi yang sesuai. Keefektifan berbicara juga dipengaruhi oleh penggunaan tekanan, nada, sendi, dan durasi dalam berbicara juga mempengaruhi kualitas pembicaraan seseorang. Tekanan suara yang tepat dalam berbicara mempengaruhi kejelasan makna bahasa yang dikemukaka oleh seseorang.

3. Penggunaan pilihan kata (diksi) yang tepat. Penggunaan pilihan kata atau diksi yang tepat dapat mempengaruhi kualitas pembicaraan seseorang sehingga mudah dipahami oleh awan bicara. Oleh karena itu pilihan kata harus tepat, jelas dan bervariasi. Pembicara sebaiknya memilih kata yang jelas dan mudah dipahami. Pembicara harus jeli dalam memilih kata-kata yang tepat, cermat, dan ekonomis.

4. Ketepatan sasaran atau maksud pembicara. Ketepatan sasaran dan maksud pembicara tidak lepas dari penggunaan suatu kalimat efektif yang diharapkan mampu diterapkan dengan baik. Hal ini bertujuan agar maksud dan tujuan serta makna yang ingin disampaikan dapat dimengerti pendengar. Kalimat efektif dalam bahasa lisan ini mempunyai ciri, yaitu: a) Keutuhan; b) Perpautan; c) Pemusatan perhatian; dan d) Kehematan.

5. Sikap wajar, tenang, dan tidak kaku. Penampilan yang tenang dan luwes pada awal pembicaraan dapat member kesan yang positif terhadap lawan bicara.

6. Pandangan harus diarahkan ke lawan bicara. Pandangan yang diarahkan pada lawan bicara mampu menciptakan situasi yang harmonis, maka hindarilah posisi membelakangi lawan bicara. Posisi seperti ini dapat menimbulkan penilaian negatif.

7. Gerak-gerik dan mimik yang tepat. Penampilan yang disertai gerak-gerik, dan mimic yang tepat dapat pula menunjang keefektifan dalam berbicara. Gerak-gerik dan mimik harus disesuaikan dengan isi pembicaraan serta jangan terlalu berlebihan. Hal ini mengindari kebosanan dan kejenuhan lawan bicara.

8. Kelancaran dan relevansi penalaran. Ketidaklancaraan pembicaraan seseorang dapat diakibatkan karena pengaruh kurang lancarnya kerja alat ucap pembicara dan kurangnya pemahaman atau wawasan terhadap materi yang sedang dibicarakan. Bahkan dapat terjadi karena adanya beban psikologis yang dialami oleh lawan bicara sendiri.

Hambatan Berbicara Efektif dalam Situasi Formal

Faktor penghambat keefektifan berbicara terdiri atas dua macam, yaitu hambatan internal dan eksternal. Hambatan internal adalah hambatan yang berasal dari 
dalam diri pembicara, sedangkan hambatan eksternal adalah hambatan yang berasal dari luar pembicara. Adapun hambatan internal yang dimaksud terdiri atas tiga bagian, yaitu sebagai berikut.

1. Hambatan yang bersifat fisik, antara lain meliputi alat ucap yang sudah tidak sempurna lagi, kondisi fisik yang kurang segar, dan kesalahan dalam mengambil postur dan posisi tubuh

2. Hambatan yang bersifat mental atau psikis, terdiri atas dua bagian, yaitu: hambatan mental yang temporer dan hambatan mental yang laten. Hambatan mental yang temporer misalnya rasa malu, rasa takut, dan rasa ragu atau grogi. Hambatan mental yang bersifat laten ada empat jenis yaitu tipe penggelisah, tipe vokalis, tipe penggumam, dan tipe tuna gairah;

3. Hambatan lain-lain meliputi:

a. Kurangnya penguasaan kaidah yaitu tata bunyi, tata bentuk, tata kalimat, dan tata makna;

b. Kurangnya pengalaman dalam hal berbicara;

c. Kurangnya perhatian pada tugas yang diemban di bidang berbicara; dan

d. Adanya kebiasaan yang kurang baik.

Sedangkan hambatan eksternal meliputi: (1) Hambatan yang berupa suara, dapat berasal dari dalam ruang atau dari luar ruang; (2) Hambatan yang berupa gerak, sering terjadi dalam berbicara informal, misalnya di atas bus kota, kereta, atau pesawat. Sedangkan pada kondisi formal jarang dijumpai; (3) Hambatan yang berupa cahaya, dapat terjadi jika pembicaraan dilakukan di malam hari atau ruang yang gelap tanpa pencahayaan; (4) Hambatan yang berupa jarak, hal ini sering terjadi jika pendengar atau pembicara tidak memperdulikan pentingnya pengaturan jarak bicara antara pembicara dengan pendengar.

\section{SIMPULAN}

Komunikasi adalah salah satu aspek paling mendasar dalam kehidupan manusia, baik secara lisan maupun tulisan. Berbicara merupakan bentuk komunikasi secara lisan. Berbicara dianggap sebagai hal yang terjadi begitu saja, akan tetapi dalam situasi formal, Berbicara dapat terbagi menjadi beberapa jenis seperti berpidato, diskusi, wawancara, persentasi, konferensi, debat, seminar dan wawancara. Dimana dalam kegiatan tersebut terdapat aturan, tata karma, dan etika tertentu yang harus dimengerti dan diterapkan dalam pelaksanaannya. Berbicara yang baik, tertutama dalam situasi formal hendaklah memperhatikan syarat-syarat atau faktor-faktor keefektifan dalam berbicara agar lawan bicara mampu memahami isi pembicaraan dan mampu menciptakan situasi yang kondusif serta efektif agar kegiatan berbicara tersebut dapat dikatakan komunikatif. Berbicara formal dalam aktivitas penalaran ialah pembicaraan yang bermakna dan mampu dijangkau oleh daya nalar lawan bicara maupun pembicara. 


\section{CATATAN AKHIR:}

1. Djago Tarigan, dkk. Pengembangan Keterampilan Berbicara, Jakarta: Departemen Pendidikan dan Kebudayaan, 1997, h. 34.

2. Herdiansa, "Cara berkomunikasi yang baik dan benar", hediasasrawan. blogspot.co.id/ 2012/11/cara-berkomunikasi-yang-baik-dan-benar.html?m=1.diakses 23 November 2016.

3. Asdam, Muhammad. Bahasa Indonesia Pengantar Pengembangan dan Kepribadian dan Intelektual. Cet II. Makassar: LIPa. 2016, h. 166-171.

4. Ibid.

5. kbbi.web.id

6. Asdam, op cit., h. 181-184

7. Kisyani Laksono, Berbicara, Jakarta: Departemen Pendidikan Nasional, 2003, h. 12.

8. Asdam, op cit., h. 15.

9. Taryono, Berbicara dan Komponen-komponenya, Bandung; Angkasa, 1999, h. 68.

10. Ibid., h. $72-77$.

11. Zamzani Haryadi, Peningkatan Keterampilan Berbahasa Indonesia, Yogyakarta: Departemen Pendidikan dan Kebudayaan, 1996, h. 322-325.

\section{DAFTA R PUSTAKA:}

Asdam, Muhammad. Bahasa Indonesia Pengantar Pengembangan dan Kepribadian dan Intelektual. Cet II. Makassar: LIPa. 2016.

Haryadi, Zamzami. Peningkatan Keterampilan Berbahasa Indonesia. Yogyakarta: Departemen Pendidikan dan Kebudayaan. 1996

Herdiansa. Cara Berkomuikasi yang Baik dan Benar. Online (hediasasrawan. blogspot. co.id/2012/11/cara-berkomunikasi-yang-baik-dan-benar.html?m=1. Diakses 23 November 2016.

Laksono, Kisyani. Berbicara. Jakarta: Departemen Pendidikan Nasional. 2003

Tarigan, Djago, dkk. Pengembangan Keterampilan Berbicara. Jakarta: Departemen Pendidikan dan Kebudayaan. 1997

Taryono. Berbicara dan Komponen-komponenya. Bandung: Angkasa, 1999.

Pusat Bahasa Departemen Pendidikan Nasional. Kamus Besar Bahasa Indonesia. Edisi Ketiga. Cet. III; Jakarta: Balai Pustaka, 2005. 